\title{
The Effect Of Self Efficacy Towards Independency Level Of Post-Stroke Patient In General Hospital Neuro Policlinic Ulin Banjarmasin
}

\author{
Eirene E.M.Gaghauna, Bagus Rahmat Santoso \\ Universitas Sari Mulia, South Kalimantan, Indonesia \\ Corresponding author:eirenegaghauna@gmail.com
}

\begin{abstract}
Background: Stroke is a disease of brain function disorder of the nerves in the form of local and global roomates have impact to physical and physcological. Stroke is the third causes of death in Indonesia and in South Kalimantan every 9.2 per mill areas, stroke cases had happened. There are 1258 cases in 2015 hospitalized in Ulin General Hospital.

Purpose: To analyze the effect of self-efficacy on towards the Independence level of post-stroke patient in general hospital neuro policlinic Ulin Banjarmasin

Methods: The methodology that use in this study is descriptive analytics, the total respondents in this study is 33 respondents. Collecting the data in this study is using the Stroke Self-Efficacy and Barthel index questionare. The Data Analyzed by Kendal Tau test Result: According to this study to 33 respondent Obtained results. The respondents who have high self efficafy as $25(75.7 \%)$, moderate self efficacy as many as seven respondents $(21.2 \%)$ and has low self-efficacy is one respondents (3.0\%) and to the independence levelof post-stroke patient variables who had Categorized to independence are 14 respondents $(42.4 \%)$, need minimal assistance 5 respondents $(15.2 \%)$, partially need assistance in three respondents $(9.0 \%)$, dependece assistance is five respondents $(15.2 \%)$ and total assistance in six respondents $(18.2 \%)$. the analysis result by Kendal Tau get $\mathrm{p}$ value $=0.044$. the strength of the correlation is $r=310$ it was statethat signifficant there is a moderate correlation and the direction are positive correlation.
\end{abstract}

Conclusion: There signifficant There is correlation between self-efficacy to the Independence level of post-stroke patient

Keywords : Self-efficacy, Independence level, stroke, post stroke

Received: January 12, 2019; Revised : February 24, 2019; Accepted March 14, 2019

How to Cite: Gaghauna, E.E.M., \& Santoso, B.R. (2019). The Effect Of Self Efficacy Towards Independency Level Of Post-Stroke Patient In General Hospital Neuro Policlinic Ulin Banjarmasin. Journal Of Nursing Practice. 2(2). 130-135. https://doi.org/10.30994/jnp.v2i2.56 


\section{BACKGROUND}

Stroke is a health problem that needs special attention. According to the WHO as many as 15 million people in worldwide suffer a stroke. About 5 million suffered permanent paralysis (WHO, 2013). Sstroke is the third leading cause of death in Indonesia after heart disease and cancer. Number of patients with stroke in Indonesia synonymous with obesity due to high fat or cholesterol diet (Aru, 2009). It is estimated that 1 in 3 people will have a stroke and 1 in 3 people will die from stroke. Indonesian stroke Foundation said that the incidence of stroke according to the data base hospital about 63 per 100,000 population aged over 65 years had a stroke, while the number of patients who died more than 125,000 inhabitants per year (Junaidi, 2011).

The prevalence of stroke in South Kalimantan is the highest among the provinces on Borneo island in the amount of 9.2 per mil, while the province of West Kalimantan, namely 5.8 per mil, 6.2 per mil of Central Kalimantan, East Kalimantan 7.7 per mile. (Riskesdas, 2013) Based on the medical records of hospitals Ulin Banjarmasin in 2015 the number of visits as many as 1,258 cases of stroke, and in 2016 as many as 1,683 cases, while the number of visits in the poly nerve in August, September and October 2017 there were 107 cases.

Stroke is a disease of the brain in the form of nerve function disorders local and global, emerged suddenly, progressive, and fast (Ministry of Health, 2013). The most common symptoms of a stroke is sudden weakness or numbness of the face, arm or leg, most often on one side of the body. Other symptoms include: confusion, trouble speaking or understanding speech, trouble seeing in one or both eyes, trouble walking, dizziness, loss of balance or coordination, severe headache with no known cause in, unconscious or not sadarakan themselves. The effects of a stroke depend on which part of the brain that is injured and keparahanya level, a very severe stroke can cause sudden death (WHO, 2015).

Suffered a stroke which can carry a neurological disorder such as reduced motor skills and muscle limbs, cognitive, visual and coordination significantly. Stroke survivors become dependent on the help of others in performing daily life activities such as eating and drinking, bathing, dressing and so on. Independence and mobility of a person suffering from a stroke to be reduced or even disappear (Wirawan, 2009).

In addition to the physical changes of stroke also causes psychological disorders, such as lack of confidence, low self-esteem, self-closing and stress that can impede the rehabilitation process. Psychological problems are also associated with Self Efficacy namely self-assessment, which started from a judgment about whether to take action is good or bad, right or wrong, can or can not do according to requisite. High self-efficacy are very important to avoid stress because the client can adapt to the situation and motivate clients to follow a rehabilitation program. Environmental, social and psychological aspects sometimes often forgotten in the client's care after a stroke, but this is an important aspect in supporting the healing process. Increasing self-efficacy will raise the confidence, self-esteem and spirit of the patient to recover. With so clients will not feel embarrassed with the situation now, accept all of his ordeal willingly and gracefully (Alwisol, 2016). Clients with Self Efficacy high are more likely to choose healthy behaviors that can increase the independence of the fulfillment of his daily activities so as to reduce depression, lowering concerns will fall, increasing self-esteem, and improve quality of life. Self Efficacy with the role of motivation and self-confidence is an important part of health seeking behavior (Fauziah, 2012). receive all of his ordeal willingly and gracefully (Alwisol, 2016). Clients with Self Efficacy high are more likely to choose healthy behaviors that can increase the independence of the fulfillment of his daily activities so as to reduce depression, lowering concerns will fall, increasing self-esteem, and improve quality of life. 
Self Efficacy with the role of motivation and self-confidence is an important part of health seeking behavior (Fauziah, 2012). receive all of his ordeal willingly and gracefully (Alwisol, 2016). Clients with Self Efficacy high are more likely to choose healthy behaviors that can increase the independence of the fulfillment of his daily activities so as to reduce depression, lowering concerns will fall, increasing self-esteem, and improve quality of life. Self Efficacy with the role of motivation and self-confidence is an important part of health seeking behavior (Fauziah, 2012).

Researchers was conducted a preliminary study on the Nerve polyclinic Ulin General hospital to 8 patient post-stroke, there are 2 clients post stroke complaint such as confusion, dizziness, numbness on hand and foot, loss of body balance, and 6 people experience muscle weakness, 4 people with muscle weakness right part of the body, and two people experience muscle weakness left side of the body. From 8 client after a stroke, as many as six people said difficulty in performing daily activities. A total of 2 clients post stroke necessitates assistance to walk and climb down the ladder. While post-stroke 2 clients need help to get dressed and 2 clients poststroke say need help to bathe and put yourself when getting out of the toilet.

There are 3 of 8 klien poststroke doubts that it can run at once, but they still believe one day be able to walk and perform activities that can not be done if they were actually recovered. While 2 of 8 clients post stroke was convinced that he can recover quickly because it has a friend who can recover from a stroke after undergoing routine treatment and therapy provided. While three people after a stroke clients feel less confident to perform activities independently since they require a healing process that takes a long time.

\section{OBJECTIVE}

This research aims to determine effect of self-efficacy in stroke clients with disabilities/weakness of a stroke and the ability of clients in independence activities. Nurses play an important role as educators to provide the right information at Stroke sufferers of the disease, prevention, complications, treatment, and management of stroke including improving self-efficacy so that clients become self-sufficient.

\section{METHODS}

This research is quantitative descriptive research, penggambilan samples in this study using the accidental sampling. Researchers put the question to respondents as many as 13 items of self-efficacy using questionnaires The Stroke Self-Efficacy Questionnaire and measure levels of independence using Barthel index with 10 items of questions about the activity daily living. The population of this research are post-stroke clients who undergo outpatient treatment at hospitals nerve poly Ulin Banjarmasin. The sample in this study as many as post-stroke clients who undergo outpatient treatment at hospitals nerve poly Ulin Banjarmasin totaling 33 people.

\section{RESEARCH RESULT}

A. Univariate analysis

\section{Self-efficacy client after stroke}

Table. 2 Distribution of frequency of Self Efficacy post stroke patient in neuro polyclinic Ulin General Hospital Banjarmasin

\begin{tabular}{ccc}
\hline Category Self Efficacy & Frequency & $\mathbf{( \% )}$ \\
\hline self Efficacy High & 25 & 75.7 \\
\hline self Efficacy moderate & 7 & 21.2 \\
\hline
\end{tabular}




\begin{tabular}{ccc}
\hline self Efficacy Low & 1 & 3.0 \\
\hline Total & 33 & 100
\end{tabular}

Table. 1 shows the 33 respondden by 25 (75.7\%) people have a higher Self Efficacy.

\section{The level of client independence after stroke}

\begin{tabular}{ccc}
\hline Level of independence & Frequency & $\mathbf{( \% )}$ \\
\hline Independence & 14 & 42.4 \\
\hline Requires minimal assistance & 5 & 15.2 \\
\hline Addiction partially & 3 & 9.1 \\
\hline Very dependence & 5 & 15.2 \\
\hline Total dependence & 6 & 18.2 \\
\hline Total & 33 & 100
\end{tabular}

Table 2 Frequency Distribution Client independence after a stroke at hospitals nerve Poly Ulin Banjarmasin.

B. Analysis Bivariat

Table 3 the effect of self-efficacy on the level of independence post-strroke patient in Nerve polyclinic Ulin general hospital Banjarmasin

\begin{tabular}{|c|c|c|c|c|c|c|c|c|c|c|c|}
\hline self Eficacy & & & & & & aut & & & & & \\
\hline & $a$ & $\%$ & $\mathrm{~b}$ & $\%$ & $\mathrm{c}$ & $\%$ & $\mathrm{~d}$ & $\%$ & $\mathrm{e}$ & $\%$ & Total \\
\hline Low & 1 & 3.0 & 0 & 0 & 0 & 0 & 0 & 0 & 0 & 0 & $1(3.0 \%)$ \\
\hline moderate & 1 & 3.0 & 2 & 6.1 & 2 & 6.1 & 1 & 0 & 1 & 0 & 7 (21.2) \\
\hline High & 4 & 12.1 & 3 & 9.1 & 1 & 3.0 & 4 & 12.1 & 13 & 39.4 & $25(75.7)$ \\
\hline Total & 6 & 18.2 & 5 & 15.2 & 3 & 9.1 & 5 & 15.2 & 14 & 42.4 & $33(100 \%)$ \\
\hline $\begin{array}{l}P=0044 \\
\text { a: Total depe } \\
\text { b: Very depe } \\
\text { c: Partial dep } \\
\text { d: Requires } 1 \\
\text { e: Independe }\end{array}$ & $\begin{array}{l}\mathrm{r}=310 \\
\text { ndenc } \\
\text { ndenc } \\
\text { enden } \\
\text { ninim } \\
\text { nt }\end{array}$ & SS & $\alpha=0$. & & & & & & & & \\
\hline
\end{tabular}

Based on Table 3 shows the results of statistical relationship between the variables of self-efficacy to the degree of independence of the clients after stroke in Poli Saraf Hospital Ulin Banjarmasin using correlation Kendall Tau result $p=0.044$ for $p<0.05$ then stated that the effect of self efficacy with a degree of independence clients post stroke in hospitals nerve poly Ulin Banjarmasin is meaningful and value of the correlation coefficient $r=310$ which indicates the direction a positive influence or direction of the degree of correlation being. Positive direction shows that the higher the client's self-efficacy higher level of independence after a stroke at nerve polyclinic Ulin general hospital.

\section{DISCUSSION}

1. Self Efficacy post-stroke clients who perform outpatient treatment at hospitals nerve Poly Ulin Banjarmasin.

The results of the study on 33 participants had a stroke in nerve polyclinic Ulin general hospital on self-efficacy almost the majority of respondents have high self-efficacy as much as $75.7 \%$. Self efficacy is a self-assessment of whether to take action is good or bad, right or wrong, can or can not (Alwisol, 2016). Self-efficacy is 
high on the client due to several factors, including the sex of the observations of researchers client poststroke who carry out checks on poly nerve Hospital Ulin Banjarmasin majority of men where line with Bandura's theory that says men have self-efficacy higher in comparison women. Because men have a higher responsibility and have the important status and role in the family, on the other family support also contribute to the high self-efficacy in post-stroke clients in hospitals nerve poly hasisl Ulin Banjarmasin in discussions with the client family support research into the role pentingdengan Henny 2018 that support good / positive that the family is able to increase the survival rate of self-efficacy. It is characterized by client motivation to follow treatment and rehabilitation.

2. The level of client independence after a stroke at hospitals nerve poly Ulin Banjarmasin

Based on the analysis in this study can be seen that clients post stroke were categorized as much as $43.4 \%$ self-sufficient. Daily activities are the principal activities of self-care that includes toileting, eating, dressing, dress, bathe and change places. The ability to perform activities of daily living are the basis of one's health level assessment and an absolute basic requirement expected by every human being (Tamher, 2009). Clients are saying post-stroke independent if the value after the measurement using the Barthel index is 80-100.

From the discussion with the client after a stroke most of the respondents do its own activities, although should hinge by hand is healthy, it is stated by the respondents as most of them said that despite the keterbatas physical but independence in performing activities of daily living may be trained to continue to get used to do it. Along with the gift of study (2015) that the high level of independence of the respondents because respondents often do activity Daily Living, respondents were also diligent and obedient in carrying out the treatment, either at home or in medical rehabilitation.

3. The influence of self-efficacy on the level of client independence after a stroke at hospitals nerve poly Ulin Banjarmasin

Based on Table 3 can be concluded that there is a relationship between self-efficacy to the level of independence of the clients after stroke in Poli nerve Hospital Ulin Banjarmasin with $\mathrm{p}=0.044, \mathrm{r}=310$, with the strength of the correlation was and the direction of a positive correlation where the higher self-efficacy, the higher the degree of independence client post-stroke of proficiency level results it can be concluded that the higher self-efficacy, the higher the client independence after a stroke. Most clients who have high self-efficacy of $75.7 \%$, is a standalone client dikegorikan as many as 42.4\%. From the results of the research in post-stroke get that client that high self-efficacy is a standalone client that fall in line with Bandura's theory in which a person who has high self-efficacy will have higher morale in performing certain tasks than people who have a low self-efficacy. Improving self-efficacy to be important in clients with routine treatment so that the health status and quality of life to be increased just as research mishali 2011 Increased self-efficacy can increase compliance with treatment. As in post-stroke clients in hospitals nerve poly Ulin Banjarmasin majority of them are clients who are excited and undergo routine examination and rehabilitation. In line with the research maujean \& davis 2013 where self-efficacy become an important role in increasing the degree of individual well-being after a stroke, the stronger the self-efficacy individuals greater efforts in overcoming difficulties. Self-efficacy contributes to overcome and menegurangi symptoms in individuals living with chronic medical conditions.

Someone who has high self-efficacy believe that they will be able to cope with events and situations effectively. High self-efficacy also decreases the fear of failure, 
increase aspirations, improve the way of solving problems and the ability to think analytically. High self-efficacy increase Confidence in the ability of self, run the therapy adherence and promote the spirit of post-stroke clients to improve and control its ability to pass the independence of self care to maintain and improve health status. It can be concluded that there is a relationship between self-efficacy with a bunch of post-stroke client's level of independence. this is because a high confidence in themselves encourage clients to be more forceful treatment, rehabilitation and able to undergo daily activities and self-care independently. It can be concluded artifacts influence of self-efficacy to the degree of independence of the post Stroe clients nerve Dipoli Hospital Ulin Banjarmasin.

\section{CONCLUSION}

Based on the research to 33 respondents of post stroke in neuro polyclinic Ulin general hospital about the effect of Self efficacy to the Independence level of post stroke patient There signifficant correlation between self-efficacy to the Independence level of post-stroke patient and the correlation are positive correlation, high self efficacy will affect to the high level of independence, a high self efficacy is a strong spirit to the patient to do their therapy, rehabilitation and independently do their daily activity living.

\section{REFERENCE}

Alwisol. 2016. Psikologi Kepribadian. Malang: UMM Press

Badan Penelitian dan pengembangan Kesehatan. 2013. Riset Kesehatan Dasar (RISKESDAS). Laporan Nasional. 1-384.

Aru w, Sudoyo. 2009. Buku Ajar Ilmu Penyakit Dalam, jilid II, edisi V. Jakarta: Interna Publishing.

Depkes RI. 2008. Profil Kesehatan Indonesia. Jakarta: Depkes RI

Fauziah JP, Endang S. 2012. Hubungan Antara Efikasi Diri Dengan Perilaku Mencari Pengobatan Pada Penderita Kanker Payudara di RSUD Ibnu Sina Gresik. Jurnal Psikologi dan kesehatan mental. 1: 138-144.

Junaidi, Iskandar. 2011. Stroke Waspadai Ancamanya. Yogyakarta: ANDI.

Karunia, E. 2015. Determinan kemandirian aktivitas kehidupan sehari-hari (AKS) pasca stroke. Skripsi. Surabaya : Universitas Airlangga

Maujean A, Davis P. 2013.The Relation Between Self Efficacy and Well-Being . int j phys med rehab $1: 159$

RSUD Ulin Banjarmasin. 2017. Profil RSUD Ulin Banjarmasin Tahun 2015,2016.

Wirawan RP. 2009. Rehabilitasi Stroke Pada Pelayanan Kesehatan Primer, Maj Kedokteran indonesia. 59: 61-71.

Mubarak WI, Chayatin N. 2007. Buku Ajar Kebutuhan Dasar Manusia: Teori \& Aplikasi dalam Praktik: Jakarta: EGC. 